\title{
Optimalisasi Fungsi Mesin Bubut untuk Proses Pengelasan Rotary Friction Welding dengan Menambah Jig dan Pendorong Hidrolik
}

\author{
Sunyoto', Gesang Nugroho ${ }^{2}$, Subarjan ${ }^{3}$, Agus Sasmito ${ }^{4}$ \\ 1Teknik Mesin, Universitas Gadjah Mada, email :sunyotojtmi@ugm.ac.id \\ 2Teknik Mesin, Universitas Gadjah Mada, email :gesangnugroho@ugm.ac.id \\ ${ }^{3}$ Teknik Mesin, Universitas Gadjah Mada, email : subarana@ugm.ac.id \\ ${ }^{4}$ Teknik Mesin, Universitas Gadjah Mada, email :agus.sasmito01@gmail.com
}

Submisi: 16 Agustus 2019; Penerimaan: 20 Juni 2020

\begin{abstract}
ABSTRAK
Mesin bubut adalah mesin yang banyak terdapat di berbagai laboratorium mekanik sekolah menegah maupun perguruan tinggi, yang berfungsi untuk pembentukan benda kerja logam maupun non logam. Pada penelitian ini dilakukan optimalisasi fungsi mesin bubut dengan penambahan alat bantu jig sebagai penahan gerakan berputar benda kerja di sisi diam dan hidrolik sebagai pendorong arah translasi benda kerja. Penambahan jig dan hidrolik membuat fungsi mesin bubut tidak hanya sebagai alat pembentuk logam namun akan berubah menjadi mesin las gesek untuk menyambung dua bagian benda kerja yang terpisah, dimana mesin bubut standar tidak mampu melakukannya. Penelitian dimulai dari pendataan kondisi mesin bubut, pembuatan disain jig, melakukan produksi jig, uji coba merangkai jig pada mesin bubut, dan terakhir adalah uji pengelasan gesek. Pemilihan material jig dan disain yang tepat akan sangat berpengaruh pada unjuk kerja dan efisiensi jig saat proses pengelasan gesek, dalam penelitian ini proses uji coba dan perbaikan rangkaian jig dilakukan beberapakali sehingga diperoleh disain jig dan penempatan hidrolik pendorong yang tepat. Hasil penelitian ini adalah sebuah rangkaian jig dan hidrolik portable untuk mesin bubut manual, sehingga mampu mengoptimalkan mesin bubut menjadi mesin las gesek. Rangkaian jig ini memiliki kelebihan mudah diproduksi dengan peralatan manual, mudah dibongkar pasang dengan cepat hanya oleh satu orang, mampu menahan getaran dari hasil pengelasan dan kemampuan produksi pengelasan yang cepat. Unjuk kerja Jig ditunjukan dengan hasil pengelasan yang lurus, nilai hasil uji tarik pada spesimen pengelasan sebesar 10,16 kN mendekati material dasar sebesar 18,97 kN. Jig hasil penelitian ini juga dapat dengan mudah diaplikasikan pada mesin bubut di laboratorium sekolah menengah, pendidikan tinggi maupun bengkel mekanik yang ada di masyarakat yang memiliki mesin bubut manual.
\end{abstract}

Kata Kunci : Mesin bubut; mesin las gesek; jig; hidrolik; rotary friction welding

\section{PENDAHULUAN}

Komponen mesin bubut terdiri dari satu komponen diam dan satu bagian diam, setiap bagian memiliki fungsi berbeda, sebuah struktur mesin bubut ditunjukkan pada Gambar 1. Komponen mesin las Rotary Friction Welding terdiri dari satu komponen berputar dan diam seperti ditunjukan pada Gambar 2, bagian-bagian ini memiliki kemiripan dengan mesin bubut, sehingga untuk mengoptimalkan fungsi mesisin bubut menjadi mesin rotary friction welding sangat memungkinkan dan cukup mudah dilakukan, keuntungan yang didapat didunia Pendidikan adalah memberi gambaran pada siswa tentang proses las Rotary Friction Welding. 


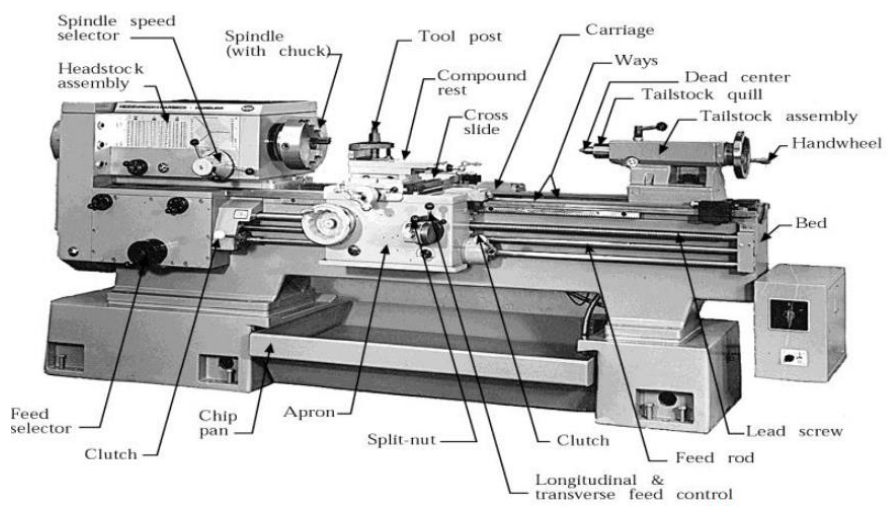

Gambar 1. Bagian-bagian sebuah mesin bubut konvensonal [1]

Berdasarkan kemiripan antara mesin bubut dan mesin las rotary friction welding maka dilakukan penelitian optimalisasi mesin bubut dengan tujuan menambah fungsi mesin bubut bukan hanya untuk proses machining saja, namun juga bisa menjadi mesin untuk proses penggabungan (joining) bahan metal. Apabila desain mesin rotary friction welding hasil optimasi mesin bubut ini diterapkan, akan membawa banyak dampak positif dimasyarakat yaitu untuk menunjang penyebaran teknologi tepat guna maupun di dunia Pendidikan untuk praktikum mahasiswa.

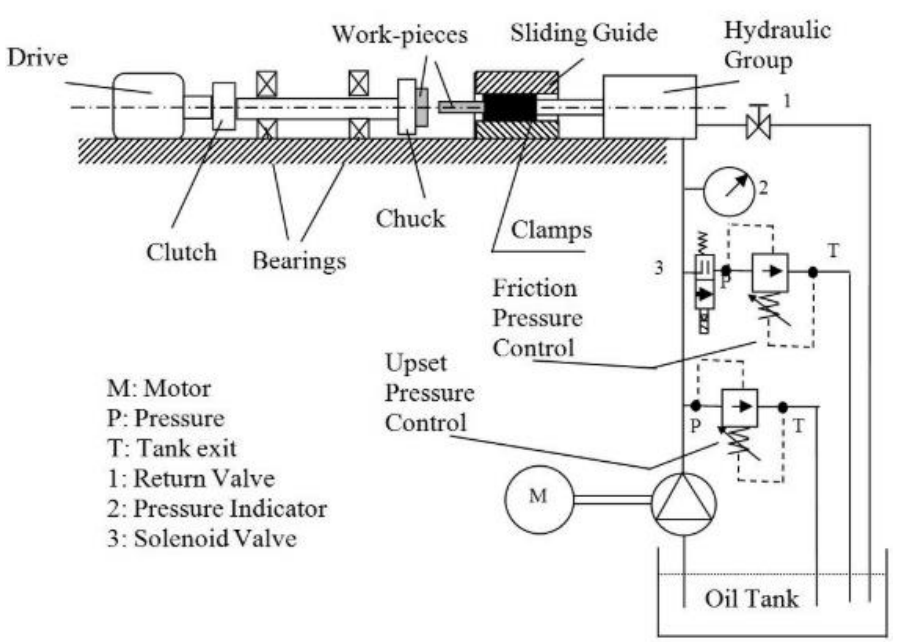

Gambar 2 Bagian-bagian sebuah mesin rotary friction welding sederhana [2].

Bila ditinjau kedepan dimana era industri 4.0 terutama pada industri otomotif pengembangan mobil listrik atau electric vehicle (EV) yang efisien konsumsi energi menjadi prioritas [3], untuk mencapai peningkatan efisiensi konsumsi energi dengan cara pengurangan berat kendaraan[4], secara aplikatif dengan pemakaian komponen atau chassis ringan, dan juga penggunaan material almunium yang mampu mengurangi berat sekitar $30 \%$ dibanding menggunakan material baja [5], maka jelas bahwa penggunaan almunium dan juga penguasaan teknologi penggabungan material almunium dalam chassis kendaraan adalah hal yang sangat diperlukan. 
Didalam riset ini mengambil posisi dan peran pengembangan teknologi joining almunium, yaitu berupa pembuatan mesin las rotary friction welding dari mesin bubut, mesin yang telah banyak populasinya di laboratorium dan di bengkel.

\section{METODOLOGI}

Penelitian ini bertujuan untuk optimalisasi mesin bubut sehingga mampu dijadikan menjadi mesin las gesek rotary friction welding, dalam upaya ini maka diperlukan beberapa bahan dan langkah-langkah tertentu, bahan-bahan yang digunakan dan runtutan penelitian dijabarkan dalam penjelasan selanjutnya.

\section{Bahan}

Dilakukan menggunakan sebuah mesin bubut manual dengan merk DoAll, yang ada di laboratorium tekonologi mekanik, Departemen Teknik mesin, Fakultas Teknik UGM. Daftar lengkap peralatan yang digunakan dalam penelitian ditunjukan pada Tabel 1.

Tabel 1. Daftar Alat dan Bahan yang digunakan dalam Penelitian

\begin{tabular}{|c|c|c|c|}
\hline No & Nama & Jumlah & Fungsi \\
\hline 1 & Mesin Bubut Merk DoAll, Seri 13", Tahun 1978 & 1 Set & Mesin dasar \\
\hline 2 & Chuck & 1 & $\begin{array}{l}\text { Pemegang Benda } \\
\text { Kerja }\end{array}$ \\
\hline 3 & Poros Pendorong diameter $45 \mathrm{~mm}$, Panjang $240 \mathrm{~mm}$. & 1 & $\begin{array}{l}\text { Menyalurkan daya } \\
\text { Dorong dari Hidrolik } \\
\text { ke spesimen }\end{array}$ \\
\hline 4 & Plat Baja jenis SS 400, Tebal $10 \mathrm{~cm}$ & $1 \times 1 \mathrm{M}^{2}$ & Bahan Membuat Jig \\
\hline 5 & $\begin{array}{l}\text { Bearing duduk, merk UCP } 209-45 \mathrm{MM} \text { OJM, } \\
\text { diamaeter } 45 \mathrm{~mm}\end{array}$ & 1 & $\begin{array}{l}\text { Tumpuan } \\
\text { Pendorong }\end{array}$ \\
\hline 6 & $\begin{array}{l}\text { Bearing tempel, merk UCF 209-45MM, diameter } 45 \\
\mathrm{~mm}\end{array}$ & 1 & $\begin{array}{l}\text { Tumpuan } \quad \text { Batang } \\
\text { Pendorong }\end{array}$ \\
\hline 7 & $\begin{array}{l}\text { Mini Powerpack Hidrolik Kapasitas } 1 \text { Ton, Merk } \\
\text { Winner }\end{array}$ & 1 set & $\begin{array}{l}\text { Pembangkit } \\
\text { dorong }\end{array}$ \\
\hline
\end{tabular}

Penjelasan lebih jauh perihal fungsi, jenis dan spesifikasi bahan-bahan yang digunakan dalam penelitian ini dijabarkan dalam sub-bab selanjutnya.

1. Mesin bubut

Bentuk mesin bubut dan bahan lain yang digunakan dalam penelitian ini ditunjukan pada Gambar 3. Pada mesin bubut terdapat chuck yang digunakan untuk memberikan putaran pada specimen, pada mesin bubut juga terdapat meja untuk menempatkan semua jig. Pada meja mesin bubut ini terdapat alur berbentuk segitiga, alur ini nantinya akan dimanfaatkan untuk menahan jig bergerak lateral.
Satu set mesin bubut yang digunakan dalam penelitian ini memiliki kondisi sama seperti dari pabrik tanpa mengalami modifikasi apapun, kemampuan putaran mesin bubut sampai 2500 RPM, dengan motor penggerak berkekutan $2.2 \mathrm{~kW}$, transmisi tenaga dari motor penggerak ke chuck dilakukan dengan sistem sabuk.

\section{Poros pendorong}

Baja yang akan digunakan sebagai poros pendorong ditunjukan pada Gambar 4, batang pendorong disini adalah batang yang akan digunakan untuk poros penyalur tenaga dorong arah translasi dari 
hidrolik menuju benda kerja pada proses penyambungan dengan las gesek. Pada penelitian ini batang pendorong dibuat dari baja ST 60 karena sifatnya yang kaku dan kuat [6], dengan diameter $45 \mathrm{~mm}$ dan panjang $280 \mathrm{~mm}$.

Pada posisi tengah arah translasi batang pendorong diberi alur pin. Pada saat dirangkai alur ini diberi pengganjal sehingga menahan batang berputar.

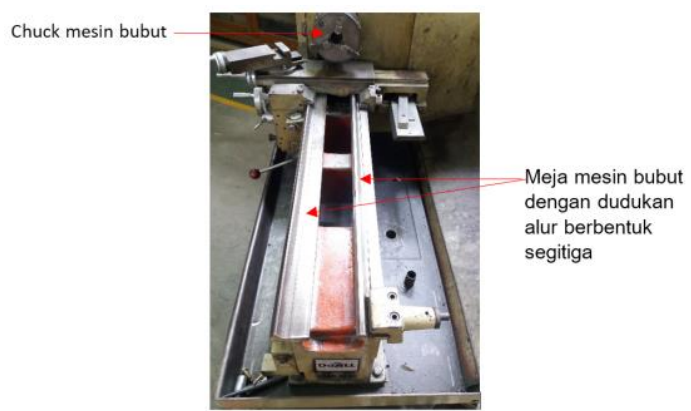

Gambar 3. Mesin Bubut merk DoAll 13" yang dijadikan sebagai bahan penelitian optimasi fungsi

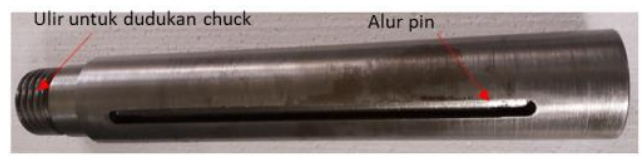

Gambar 4. Batang baja ST 60 yang akan digunakan sebagai bahan untuk membuat batang pendorong.

\section{Bearing}

Bearing yang akan digunakan terdapat 2 jenis yaitu bearing duduk dan bearing menempel seperti ditunjukan pada Gambar 5, kedua bearing memiliki diameter as $45 \mathrm{~mm}$ sesuai dengan diameter batang pendorong. Bearing jenis ini umumnya dipakai untuk poros yang bergerak memutar atau berotasi, namun dalam penelitian ini bearing akan digunakan untuk menumpu poros yang bergerak translasi, karena bearing memiliki permukaan dalam yang sangat licin maka gerakan translasi sangat dimungkinkan, apalagi dalam aplikasinya akan ada penambahan oli dipermukaan antara bearing dan batang pendorong, maka permukaan dalam bearing akan semakin licin dan gerakan translasi semakin mudah.

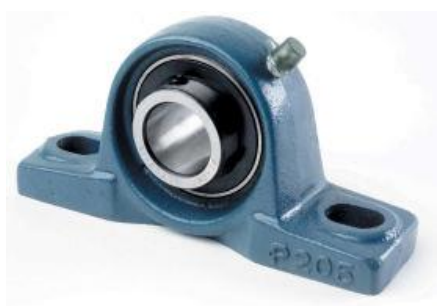

(a)

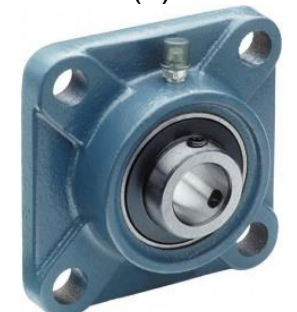

(b)

Gambar 5. Bearing yang akan digunakan untuk penumpu dan pengarah batang pendorong, Bearing jenis duduk (a), Bearing jenis menempel (b).

4. Power pack mini

Sebagai pembangkit gaya dorong yang nantinya akan digunakan untuk mendorong benda kerja ketika mesin bubut menjadi mesin las gesek, digunakan mesin hidrolik winner seperti ditunjukan pada Gambar 6 . Secara garis besar mesin ini terdiri dari pompa hidrolik, oli, solenoid dan sitim silinder hidrolik. Pompa berfungsi untuk menghasilkan tekanan pada fluida oli, selanjutnya aliran oli diatur dengan solenoid sebagai katub on/off. Gerakan maju mundur silinder hidrolik diatur dengan solenoid [7]. 


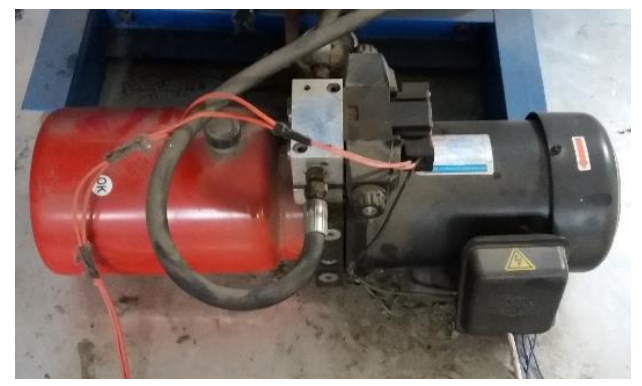

Gambar 6. Mesin powerpack mini winner yang akan digunakan untuk pembangkit gaya dorong untuk benda kerja pada arah translasi

\section{Chuck}

Untuk memegang benda kerja yang diam disisi lain, maka digunakan tambahan chuck yang umum seperti digunakan pada mesin bubut seperti ditunjukan pada Gambar 7. Chuck ini cukup kuat menahan benda kerja dan menahan getarn yang dihasilkan.

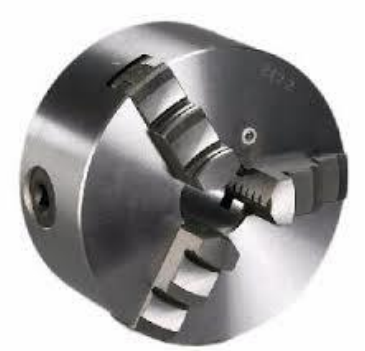

Gambar 7. Chuck yang akan digunakan untuk memegang benda kerja pada saat mesin bubut difungsikan menjadi mesin las gesek [8]

\section{Plat Baja SS 400}

Plat baja yang digunakan adalah plat baja biasa dengan jenis SS400, plat ini nantinya akan digunakan sebagai bahan membuat jig atau dudukan bagi bearing dan silinder hidrolik. Plat SS 400 digunakan dengan alasan bahwa plat baja ini memiliki kekuatan yang cukup sebagai bahan jig untuk menahan beban kerja [9], selain itu plat SS 400 juga mudah ditemukan dipasaran dengan harga yang terjangkau.
Alur Penelitian
$\begin{aligned} & \text { Dalam } \\ & \text { upaya }\end{aligned}$
mengidentifikasi
masalah menemukan solusi dalam penelitian optimasi fungsi mesin bubut menjadi mesin las gesek, maka studi awal dilakukan dimulai dari mesin bubut supaya jig dan alat bantu lain mampu menahan beban kerja, salah satu acuan runtutan alur penelitian ini adalah penelitian yang dilakukan oleh Thakare [10], ditunjukan pada Gambar 8.

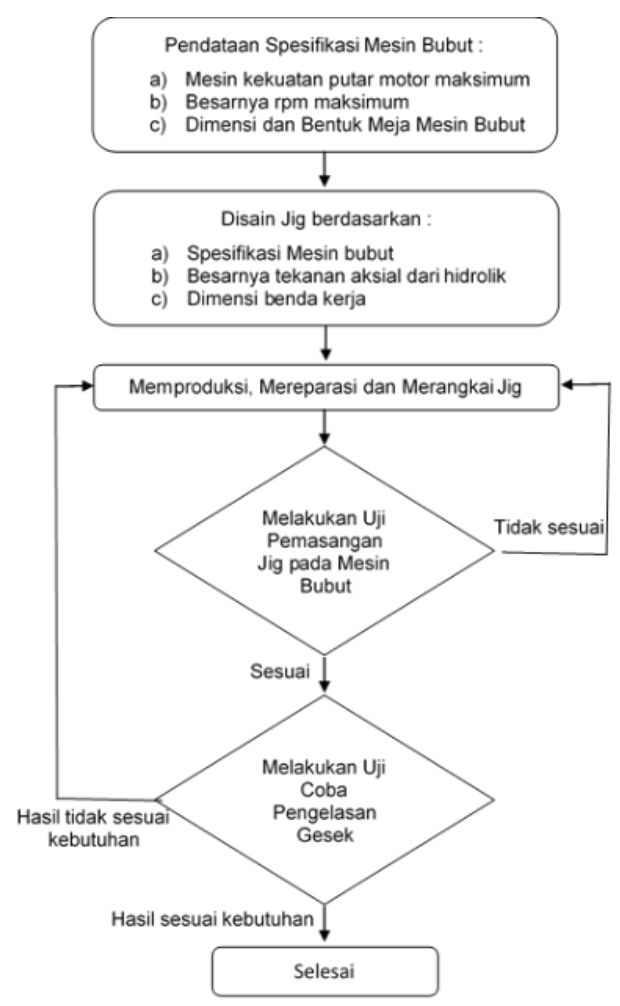

Gambar 8. Alur penelitian yang digunakan dalam penelitian optimalisasi mesin bubut untuk mesin las gesek[10].

Hasil akhir dari penelitian ini adalah sebuah rangkaian jig kokoh dan efisien yang mampu mengoptimalkan fungsi mesin bubut bukan hanya untuk pembentukan material tapi juga penyambungan material melalui proses las gesek dengan berbagai variasi putaran dan tekanan. Jig selain didisain 
kokoh, juga dibuat semudah mungkin untuk dipasang pada mesin bubut dan dapat di lepas apabila tidak diperlukan.

\section{HASIL DAN PEMBAHASAN}

Pembuatan jig dimulai dengan proses pengukuran dan penggambaran, disesuaikan dengan meja mesin bubut yang akan dibuat dan kapasitas mesin yang akan dibuat, selanjutnya plat ss 400 dipotong menjadi bagian-bagian tertentu sesuai desain, plat yang telah terpotong dirangkai dengan proses pengelasan manual sehingga menjadi jig dengan bentuk seperti ditunjukan pada Gambar 9 sampai dengan Gambar 11.

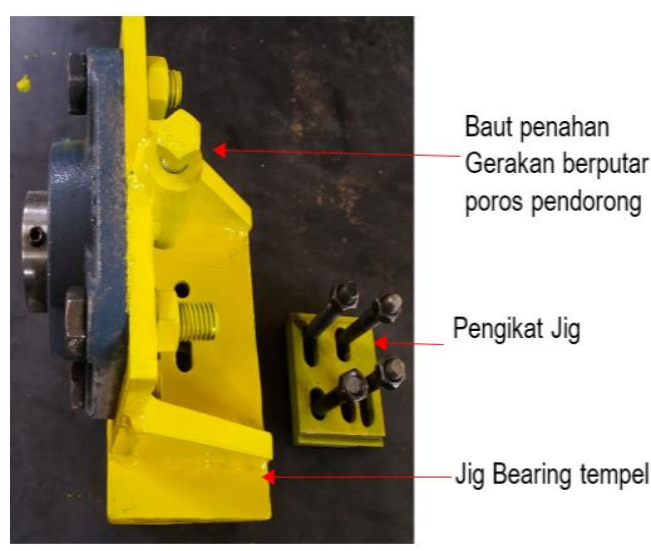

Gambar 9. Jig penahan gerakan puntir dan translasi untuk dudukan bearing tempel.

Gambar 9 menunjukan jig untuk dudukan bearing tempel, dimana bearing tempel diikat dengan kuat dengan pengaturan posisi lateral dan horizontal sedemikian rupa sehingga posisi pusat bearing berada pada center chuck mesin bubut. Disamping jig bearing terdapat pengikat jig, yang berfungsi untuk mengikat jig bearing tempel pada meja mesin bubut. Jig ini berfungsi untuk menahan Gerakan berputar dari poros pendorong akibat putaran specimen juga sebagai dudukan pengatur posisi porors pendorong.

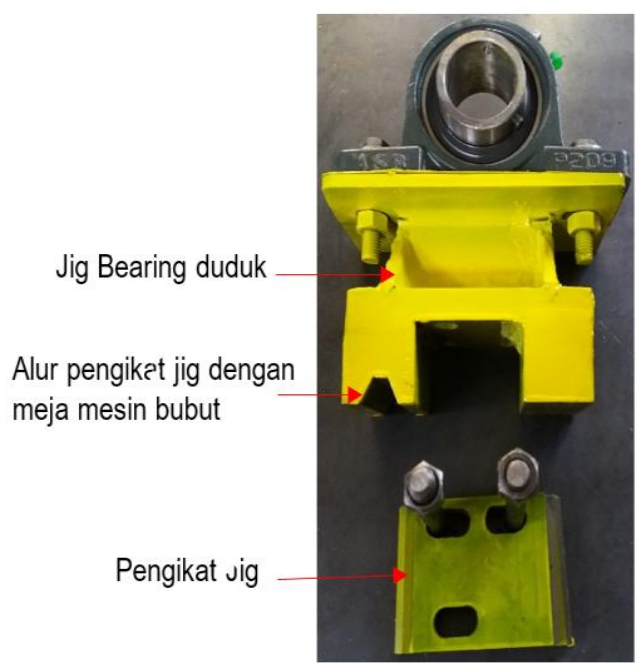

Gambar 10. Jig untuk dudukan bearing duduk.

Gambar 10 adalah sebuah jig untuk dudukan bearing, yang perlu diperhatikan adalah posisi ketinggian dari jig harus dipertimbangan dengan tepat, sehingga berada satu center dengan center chuck mesin bubut baik secara lateral maupun horizontal. Penggunaan pengganjal diantara jig dan bearing duduk sangat berguna untuk pengaturan posisi ketinggian dari bearing supaya center dengan chuck mesin bubut. Pada jig ini juga diberi alur dibagian bawah, alur ini berfungsi untuk mencengkram meja mesin bubut sehingga jig mampu menahan gerakan horizontal.

Gambar 11 adalah jig yang digunaan untuk dudukan hidrolik, pada bagian bawah terdapat pengikat jig, digunakan untuk mengikat jig dudukan aktuator pada meja mesin bubut, digunakan dua pengikat supaya mampu menahan jig aktuator tidak terdorong kebelakang saat aktuator memberi dorongan lateral pada spesimen.

Tiga jig yang telah selesai dibuat selanjutnya dirangkai diatas meja mesin bubut sesuai urutan dan fungsi masingmasing, bentuk rangkaian jig pada mesin bubut ditunjukan pada Gambar 12. 


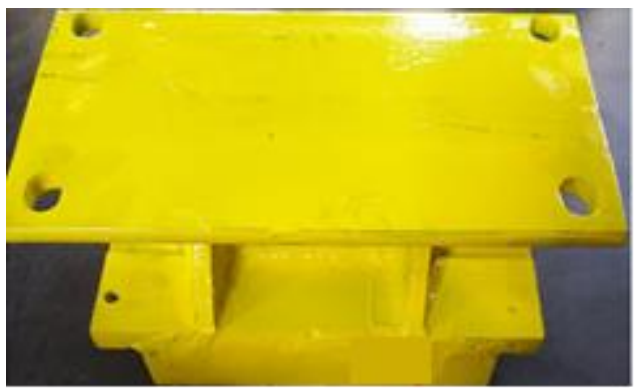

(a)

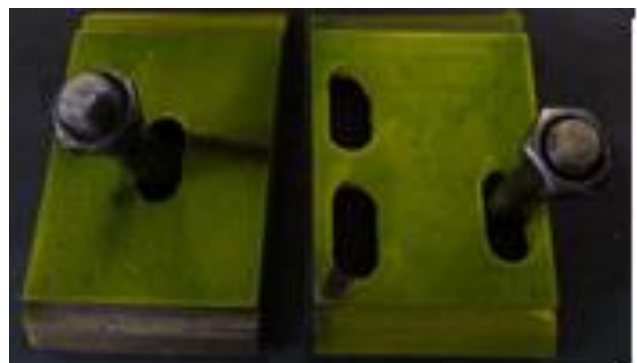

(b)

Gambar 11. Jig untuk dudukan aktuator hidrolik (a) dan pengikat jig (b)

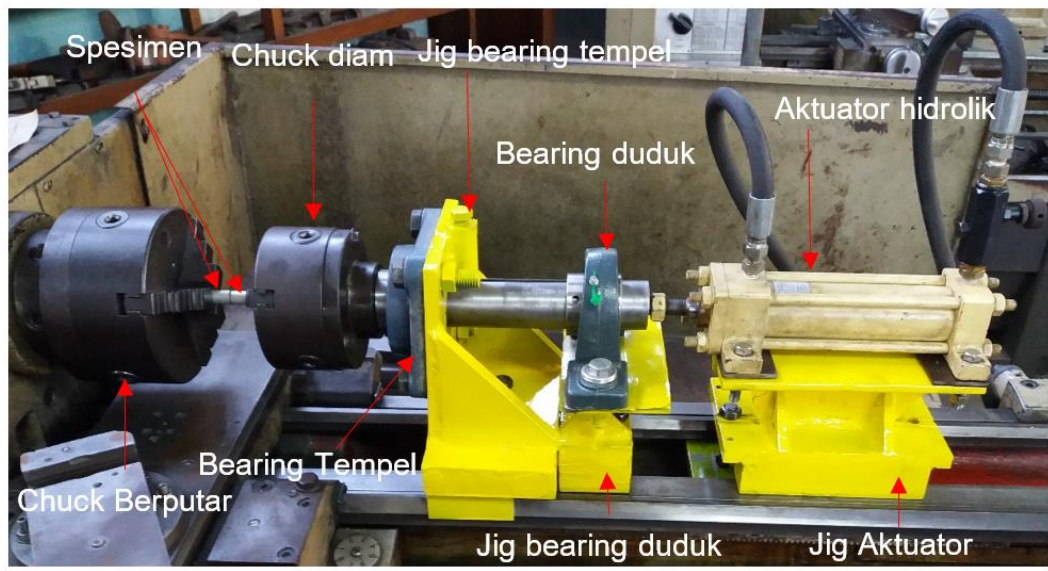

Gambar 12. Jig yang telah dirangkai dan siap dioperasikan sebagi mesin rotary friction welding.

Uji coba fungsi jig dilakukan untuk mengetahui kemampuan jig bekerja dan mampu menambah fungsi mesin bubut menjadi mesin las rotary friction welding. Uji pengelasan dilakukan pada batang almunium 6061 dengan diameter $15 \mathrm{~mm}$, dengan 3 mode pengaturan kecepatan putar chuck menghasilkan sambungan las yang berbeda bentuk. Gambar 13 menunjukan sambungan almunium hasiil uji coba.

Untuk mengetahui kekuatan hasil pengelasan maka dilakukan uji tarik dengan mengacu pada standard ASTM E8M-99 dengan bentuk spesimen uji tarik seperti pada Gambar 14.

Dimensi uji tarik mengacu pada Tabel 2 spesimen 2 , dimana nilai $R$ adalah $8 \mathrm{~mm}$, diameter $\mathrm{D}$ sebesar $9 \mathrm{~mm}$, panjang batang $A$ adalah $45 \mathrm{~mm}$.

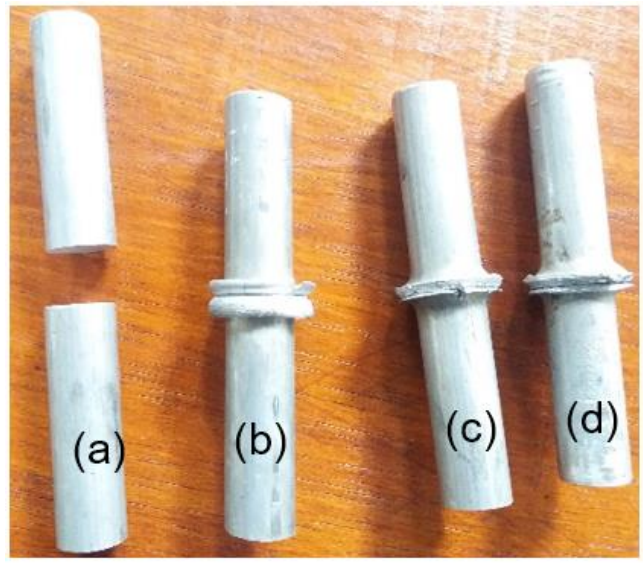

Gambar 13. Hasil pengelasan rotary friction welding menggunakan mesin hasil optimalisasi mesin bubut, spesimen sebelum disambung (a), spesimen setelah disambung dengan proses pengelasan menggunakan kecepatan putar berbeda (b), (c), (d). 
Tabel 2. Dimensi uji tarik sesuai ASTM E8M-99 [11]

\begin{tabular}{|c|c|c|c|c|c|}
\hline \multicolumn{6}{|c|}{$\begin{array}{l}\text { Dimensions, } \mathrm{mm} \text { [in.] } \\
\text { For Test Specimens with Gage Length Four times the Diameter [E8] }\end{array}$} \\
\hline & $\begin{array}{l}\text { Standard } \\
\text { Specimen }\end{array}$ & \multicolumn{4}{|c|}{ Small-Size Specimens Proportional to Standard } \\
\hline & Specimen 1 & Specimen 2 & Specimen 3 & Specimen 4 & Specimen 5 \\
\hline G-Gage length & $50.0 \pm 0.1$ & $36.0 \pm 0.1$ & $24.0 \pm 0.1$ & $16.0 \pm 0.1$ & $10.0 \pm 0.1$ \\
\hline & {$[2.000 \pm 0.005]$} & {$[1.400 \pm 0.005]$} & {$[1.000 \pm 0.005]$} & {$[0.640 \pm 0.005]$} & {$[0.450 \pm 0.005]$} \\
\hline \multirow[t]{2}{*}{$D$-Diameter (Note 1) } & $12.5 \pm 0.2$ & $9.0 \pm 0.1$ & $6.0 \pm 0.1$ & $4.0 \pm 0.1$ & $2.5 \pm 0.1$ \\
\hline & {$[0.500 \pm 0.010]$} & {$[0.350 \pm 0.007]$} & {$[0.250 \pm 0.005]$} & {$[0.160 \pm 0.003]$} & {$[0.113 \pm 0.002]$} \\
\hline$R$-Radius of fillet, $\min$ & $10[0.375]$ & $8[0.25]$ & $6[0.188]$ & $4[0.156]$ & $2[0.094]$ \\
\hline A-Length of reduced section, min (Note 2) & $56[2.25]$ & $45[1.75]$ & $30[1.25]$ & $20[0.75]$ & $16[0.625]$ \\
\hline \multicolumn{6}{|c|}{$\begin{array}{l}\text { Dimensions, } \mathrm{mm} \text { [in.] } \\
\text { For Test Specimens with Gage Length Five times the Diameter [E8M] }\end{array}$} \\
\hline & \multicolumn{2}{|l|}{ Standard Specimen } & \multicolumn{3}{|c|}{ Small-Size Specimens Proportional to Standard } \\
\hline & Specimen 1 & Specimen 2 & Specimen 3 & Specimen 4 & Specimen 5 \\
\hline G-Gage length & $\begin{array}{c}62.5 \pm 0.1 \\
{[2.500 \pm 0.005]}\end{array}$ & $\begin{array}{c}45.0 \pm 0.1 \\
{[1.750 \pm 0.005]}\end{array}$ & $\begin{array}{c}30.0 \pm 0.1 \\
{[1.250 \pm 0.005]}\end{array}$ & $\begin{array}{c}20.0 \pm 0.1 \\
{[0.800 \pm 0.005]}\end{array}$ & $\begin{array}{c}12.5 \pm 0.1 \\
{[0.565 \pm 0.005]}\end{array}$ \\
\hline$D$-Diameter (Note 1) & $\begin{array}{c}12.5 \pm 0.2 \\
{[0.500 \pm 0.010]}\end{array}$ & $\begin{aligned} 9.0 & \pm 0.1 \\
{[0.350} & \pm 0.007]\end{aligned}$ & $\begin{aligned} 6.0 & \pm 0.1 \\
{[0.250} & \pm 0.005]\end{aligned}$ & $\begin{aligned} 4.0 & \pm 0.1 \\
{[0.160} & \pm 0.003]\end{aligned}$ & $\begin{array}{c}2.5 \pm 0.1 \\
{[0.113 \pm 0.002]}\end{array}$ \\
\hline$R$-Radius of fillet, $\min$ & $10[0.375]$ & $8[0.25]$ & $6[0.188]$ & $4[0.156]$ & $2[0.094]$ \\
\hline A-Length of reduced section, $\min$ (Note 2) & $75[3.0]$ & $54[2.0]$ & $36[1.4]$ & $24[1.0]$ & $20[0.75]$ \\
\hline
\end{tabular}

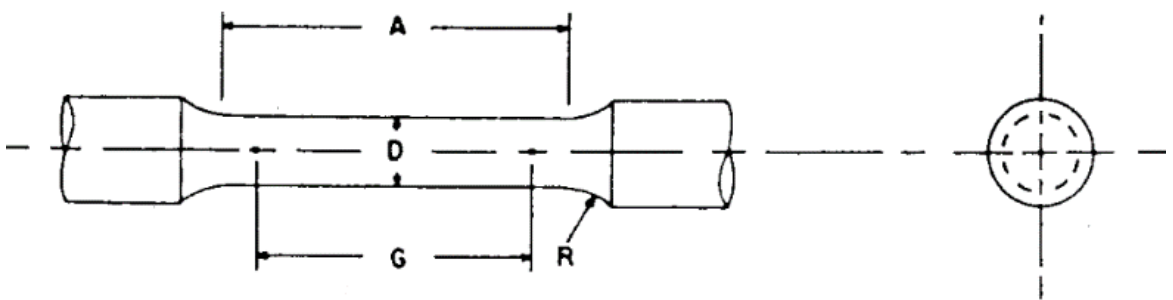

Gambar 14. Bentuk spesimen uji tarik [11]

Bentuk patahan spesimen setelah uji ditunjukan pada Gambar 16. Pada Gambar 16 (a) menunjukan spesimen hasil uji Tarik untuk material dasar, sedangkan Gambar $16 \quad$ (b),(c),(d) menunjukan spesimen hasil uji Tarik pada hasil pengelasan.

Hasil uji pada seperti pada Gambar 16 dan Gambar 15 menunjukan bahwa kekuatan tarik pada spesimen uji coba hasil las tertinggi adalah pada spesimen d sebesar 10,16 $\mathrm{kN}$ dengan nilai regangan $3,77 \mathrm{~mm}$, nilai terendah adalah 9,79 kN pada spesimen b dengan regangan sebesar $3,61 \mathrm{~mm}$. hasil uji coba pengelasan ini masih sangat awal, sehingga sangat memungkinkan untuk memperoleh kekuatan hasil las yang mendekati kekuatan material dasar a sebesar $18,97 \mathrm{kN}$.

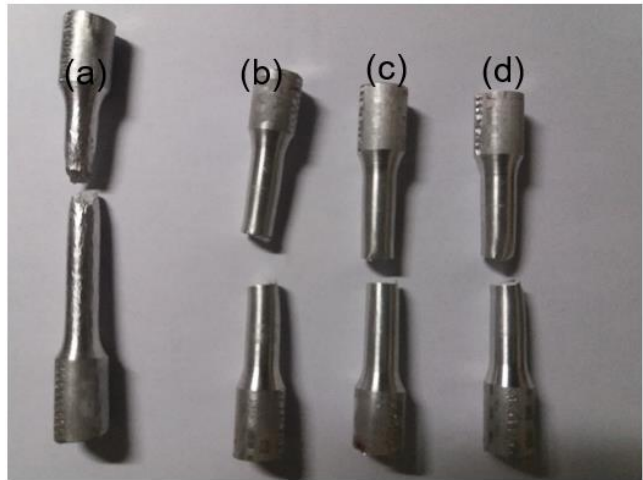

Gambar 16. Bentuk spesimen uji setelah uji Tarik, material dasar (a), spesimen hasil pengelasan (b)(c)(d).

Hasil pengujian ditunjukan pada Gambar 16, yang berisi data besarnya gaya tarik maksimum yang dimiliki spesimen $F(k N)$ dan regangan yang terjadi selama proses uji tarikan spesimen (mm). 


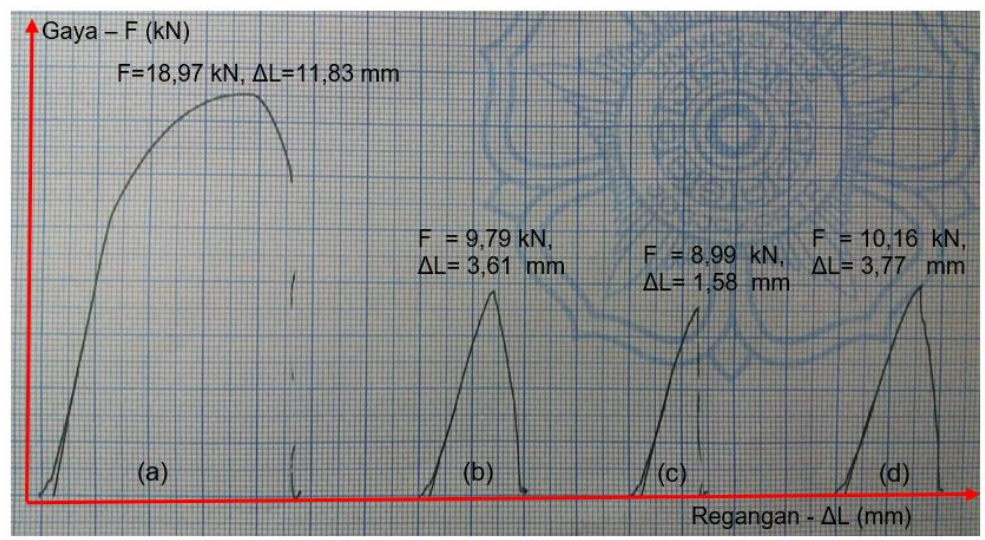

Gambar 17. Grafik hasil uji tarik pada spesimen material dasar (a), material hasil pengelasan $(b)(c)(d)$.

\section{KESIMPULAN DAN SARAN}

Berdasarkan pengamatan spesimen hasil uji coba pengelasan rotary friction welding menggunakan mesin bubut, bila diperiksa lebih lanjut, nampak bahwa spesimen sambungan sangat lurus, hal ini membuktikan bahwa jig sangat stabil dengan tingkat getaran dan defleksi yang sedikit. Bila dilihat dari bentuk sambungan menjukan perbedan antara satu spesimen dengan lainya dengan parameter pengelasan yang berbeda, hal ini menunjukan bahwa hasil optimasi mesin bubut ini sangat fleksibel dalam pemilihan parameter pengelasan, dan berdasarkan hasil uji tarik pada material hasil uji coba pengelasan dimana nilai kekuatan tarik 10,16 kN cukup mendekati kekuatan tarik material dasar sebesar 18,97 kN, Berdasarkan data-data ini membuktikan bahwa optimasi mesin bubut menjadi mesin las rotary friction welding menggunakan penambahan jig berhasil.

\section{DAFTAR PUSATAKA}

[1] L. Process and A. Z. Khalim, "Development of Semi-Automatic Lathe by using Intelligent Soft Computing Technique Development of Semi-Automatic Lathe by using
Intelligent Soft Computing Technique," Mater. Sci. Eng., vol. 324, no. 012053, 2018.

[2] M. Sahin and C. Misirli, "Mechanical and Metalurgical Properties of Friction Welded Aluminium Joints," in Intech, 2013, pp. 277-300.

[3] Y. Hori, "Future vehicle society based on electric motor, capacitor and wireless power supply," 2010 Int. Power Electron. Conf. - ECCE Asia -, IPEC 2010, pp. 2930-2934, 2010.

[4] M. Kleiner, M. Geiger, and A. Klaus, "Manufacturing of lightweight components by metal forming," CIRP Ann. - Manuf. Technol., vol. 52, no. 2, pp. 521-542, 2003.

[5] Y. Choi et al., "Forming of the precision aluminum tube for a light weight propeller shaft," J. Mech. Sci. Technol., vol. 27, no. 11, pp. 34453449, Nov. 2013.

[6] PT.steelindopersada, "www.steelindopersada.com." .

[7] B. Pramujati, "MODELLING AND SIMULATION ANALYSIS OF SOLENOID VALVE FOR SPRING CONSTANT INFLUENCE TO DYNAMIC RESPONSE," vol. 11, no. 4, pp. 2790-2793, 2016.

[8] "Chuck." [Online]. Available: https://www.industrybuying.com/self 
-centering-chucks-sharp-

TOO.SEL.41176523/].

[9] R. D. Sulamet-ariobimo, J. Wahyuadi, T. Sukarnoto, A.

Rustandi, Y. Mujalis, and D.

Prayitno, "Tensile properties analysis of AA1100 aluminium and SS400 steel using different JIS tensile standard specimen," Rev. Mex. Trastor. Aliment., vol. 14, no. 2, pp. 148-153, 2016.

[10] P. A. Thakare and L. R. Singh, "Design and Development of Micro Friction Welding Machine and Investigation of Welding Parameters for Similar Materials," Int. J. Sci. Eng. Res., vol. 5, no. 6, pp. 13791384, 2014.

[11] ASTM E8M-99, "Standard Test Methods for Tension of Metallic Materials", 2013. 